\title{
The Historical Development of the Term 'Mélange' and Its Relevance to the Precambrian Geology of Anglesey and the Lleyn Peninsula in Wales, UK
}

\author{
Margaret WOOD*
}

\begin{abstract}
Since Greenly (1919) first described a 'mélange' in Anglesey, as mixed, blocks-in-matrix rock, this has become the world's type locality for mélange. Most of Anglesey and western Lleyn consists of Late Precambrian-Cambrian Mona Complex, which is one of the best, low-grade accretionary orogenic belts in Europe. The prevailing view is that it formed by the fore-arc accretion of tectonic units above a subduction zone of West Pacific type, and thus is characterised by Ocean Plate Stratigraphy. This paper describes the change in thinking about the tectonic development of the Mona Complex and its mélanges over the last 200 years. The various types of mélange are described and their relevance to early life discussed.
\end{abstract}

Key words : Precambrian, tectonic, accretion, stromatolites, Anglesey

\section{History of research and terminology of mélange (Figs. 1 and 2)}

Research on Anglesey that involved mapping and descriptions of rocks, including the 'mélange' has been going on for 200 years. Henslow (1822), friend of Charles Darwin, made the first recognisable-today, geological map of Anglesey on which he named all the rocks on the northern coast from Wylfa through Cemaes Bay to Llanbadrig (the main area of the 'mélange' rocks) as conglomerates. Matley (1899, 1990) described rocks at Llanbadrig point as 'slaty beds with broken pieces of limestone' .

Greenly produced a revised and up-dated version of the map by Henslow (1822) and a detailed description of all the rocks in Anglesey. He recognised three groups in Anglesey's ancient

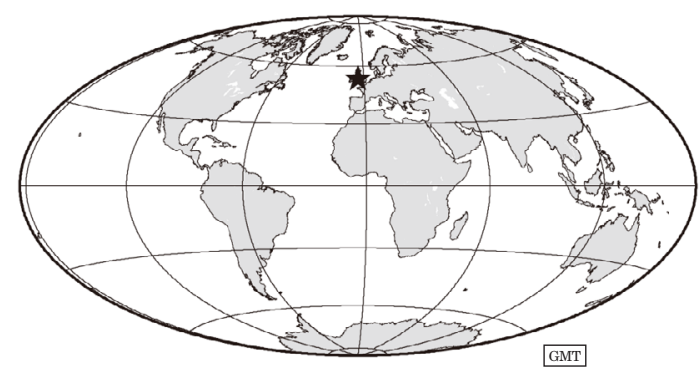

Fig. 1 Locality index of Anglesey and Lleyn, North Wales, UK.

rocks that, at that time, were all thought to be of Precambrian age. The most extensive and varied group was the Gwna Group, containing the Penmynydd-zone rocks, important for the blueschists, (now known to be high-pressure metamorphosed pillow lavas) and mélange.

\footnotetext{
* GEOMÔN Geopark, The Old Watch House, Amlwch Port, Amlwch, Anglesey LL68 9DB, Wales, UK
} 


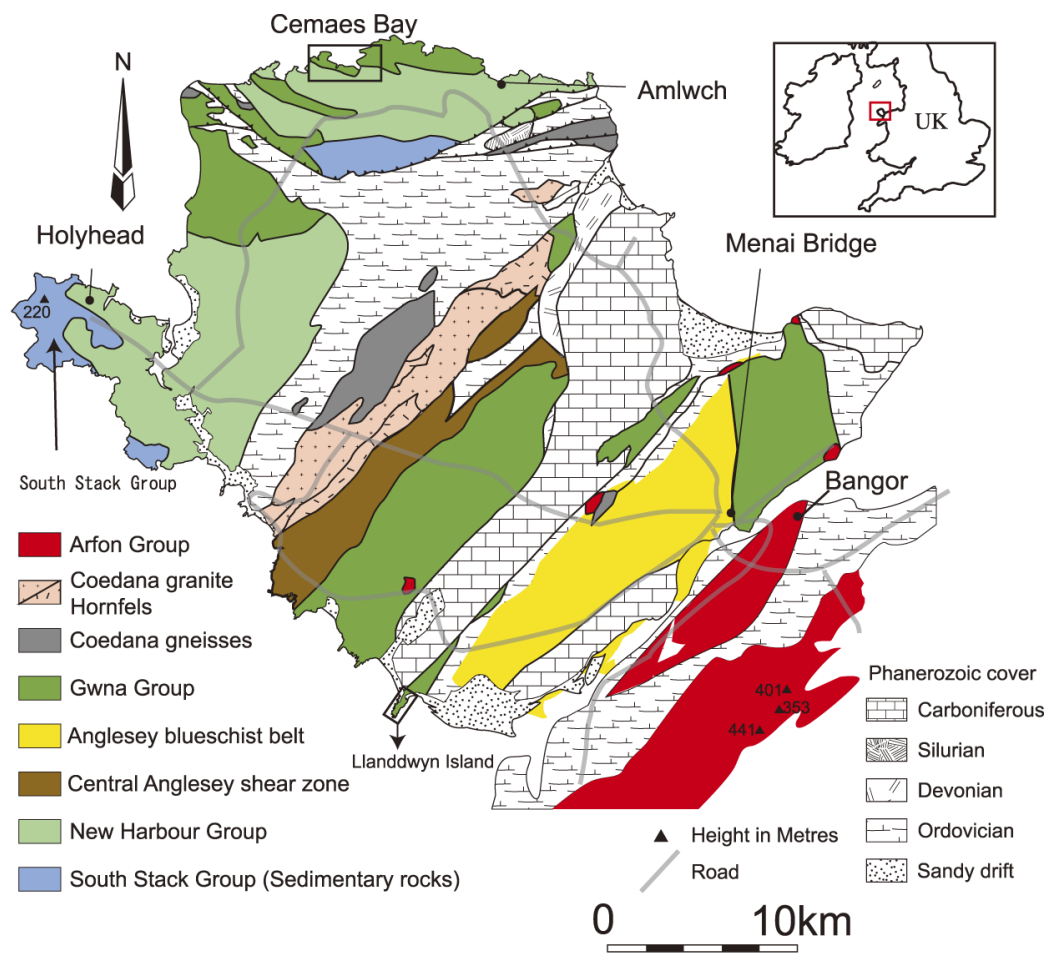

Fig. 2 Geological map of Anglesey (by S. Maruyama adapted from Greenly, 1919): showing the locations of Cemaes Bay, Llanddwyn Island and the Blueschist Belt.

Greenly wrote that "the majority of the Gwna rocks were a chaotic assemblage of limestones, radiolarites, turbidites, and basalts, which may occur associated with peridotites, gabbros and blue-schists. They are widespread among active continental margins and mountains, kilometres in size and surrounded by a plastic rock matrix", and he referred to these as mélange. He described the typical mélange as 'consisting of lenticular strips and lumps of grit floating in a schistose matrix that sweeps curving around them, which were produced by a general destruction of original junctions, whether igneous or sedimentary, and shearing down of material producing a schistose matrix in which fragments of more obdurate rocks 'float' as more obdurate lenticles. They occur in zones of fracture and can have a homogenous, structureless matrix' . Greenly (1919) described two kinds of mélange, an autoclastic general mélange containing inclusions of all other rocks, which included gigantic autoclasts of phyllite and grit mélange and an Extraordinary Mélange which contained both Precambrian and Ordovician clasts in an Ordovician shale matrix. Matley as early as 1899, used the term 'crush breccia' and 'cataclastic slates and grits' to describe the rocks of Lleyn that originated as an extension of the Gwna Mélange in Anglesey. The mélange of Anglesey was compared by Bailey and McCallien (1953) with the Ankara rocks in Turkey and by Gansser, 1955 when describing the Coloured Mélange of Central Iran. Shackleton (1953) questioned the findings of the last three writers as he thought there was a lack of evidence for an overriding mass. He subsequently stated (1954) that there was more than one type of mélange in the Gwna Group, and one was a submarine slide breccia. Hsü (1966) described the mélange as of tectonic significance. Over the decades there has been confusion over the terminology and origins of mélange. It is only since the 1960's, when plate tectonics was advocated that the importance 
Table 1 The Thickness of the Mona Complex Groups (unpublished data, Wood, 1985).

\begin{tabular}{|c|c|c|}
\hline \multicolumn{3}{|c|}{ Fydlyn Group (Arvonian volcanics of mainland North Wales) } \\
\hline Gwna Mélange & 3696 m (metres) & \\
\hline Skerries Group & $544 \mathrm{~m}$ & \\
\hline New Harbour Group & $813 \mathrm{~m}$ & \\
\hline South Stack Group --- & $\begin{array}{l}\text { - Rhoscolyn Formation } \\
\text { - Holyhead Quartzite } \\
\text { - Lower Formation }\end{array}$ & $\begin{array}{l}813 \mathrm{~m} \\
221 \mathrm{~m} \\
295 \mathrm{~m}\end{array}$ \\
\hline
\end{tabular}

of mélange formation was recognised as an integral part of the subduction process (Raymond, 1984). Despite the confusion in terminology and different origins of mélanges, it is noticeable that most authors have recognised the importance of subduction-accretionary processes; e.g. Hsü (1966) defined mélange as a tectonic breccia and wrote that tectonic models of convergent plate margins involve mélange genesis. Mélange was referred to as 'a migrating subduction zone' and suggested that mélange 'formed an accretionary prism of landward dipping, deformed turbidite and pelagic material, partially detached and plated to the bottom of a thickening mélange wedge'. The latter model accounts for the olistostromal nature of parts of the mélange with slides and flows, off a structural high or trench slope break. However, major controversies relating to the tectonic significance, and mechanism of the formation of mélange have continued into the $21^{\text {st }}$ century.

Wood (1974) considered that the Monian Complex of Anglesey rocks is unique amongst pre-Mesozoic terranes. He stated that the association of olistostromal mélanges, pillow basalts, cherts, ophiolites and local high pressure/low temperature metamorphism suggested that the Monian rocks were deposited in a trench related to a southeast-dipping subduction zone (Fig. 3). It was stated that mélange is a rock formation created from sediments and rocks scraped off the top of a downward-moving tectonic plate at a destructive plate margin like the Nankai Trough in the mouth of the subduction zone in Japan. Olistostromes were described by Abbate et al. (1970), as sedimentary deposits composed of a chaotic mass of heterogeneous material, such as blocks (olistoliths), and mud that accumulate as a semi-fluid body by submarine gravity sliding or slumping of the unconsolidated sediments. This stratigraphic unit lacks true bedding and is intercalated amongst normal bedding sequences. Olistostromes are mélange, formed under gravitational sliding under water and accumulation of flow as a semi-fluid body with no bedding. In unpublished notes D. S. Wood described the Mona Complex as consisting of 5 stratigraphic groups ranging from turbidites to minor volcanics in the central area and to olistostromal mélanges and major volcanics in the upper part. His order and thickness of Groups etc. are in Table 1. Barber and Max (1979) recognised that the contact between the South Stack group and the overlying, more highly-deformed New Harbour Group is a thrust plane. From detrital zircon ages Collins and Buchan (2004) concluded that the maximum depositional age of the South Stack Group is $501 \mp 10 \mathrm{Ma}$ and that the Monian Supergroup (Complex) was deposited between c. 500 and $475 \mathrm{Ma}$. They considered that the New Harbour Group overlies the South Stack Group but in stratigraphic, rather than tectonic, order; hence they presumed that the Gwna group with its mélanges is the youngest. Muir et al. (1979) also stated that the mélange could be no earlier than Cambrian, based on fossils in cherts associated with pillow lavas. The evidence was refuted because of the poor preservation of the fossils.

\section{Ocean Plate Stratigraphy}

As a result of their re-evaluation of the geology of Anglesey and Lleyn and in the light of comparable accretionary rocks in the West Pacific, Kawai 
et al. $(2006,2007)$ suggested that the South Stack Group was subducted and underthrust at the bottom of the accretionary complex below the already accreted New Harbour Group, and this explains why the South Stack Group has such a young age and why the Gwna Group with its mélanges contains the oldest rocks now situated at the top of the Monian pile. This understanding of the structure and growth sequence of an accretionary prism that forms in a subduction zone based on a modern Japanese analogue was successfully applied to the Southern Uplands of Scotland by Leggett (1987). Maruyama et al. (2010) reviewed the evidence in the field in many countries including Anglesey where they recognised that it is an example of Pacific type, Ocean Plate Stratigraphy (OPS), similar to the currently developing OPS in Japan. They evaluated the Neoproterozoic, Pacific-type accretionary complex on Anglesey and Lleyn by reconstructing its OPS, successively emplaced downwards in an accretionary wedge and recognised three types of OPS. The oldest type at the top, formed when an ocean opened and closed from a ridge to a trench. The central OPS suffered deep subduction and later exhumed as blueschists and the youngest at the bottom is an olistostrome-type deposit formed by gravitational collapse of previously accreted material. All formed by successive eastward subduction at the leading edge of Avalonia. As the wedge grew downward with time, the blueschist was exhumed at 550-560 Ma in the structural centre of Anglesey. Balanced sections on Llanddwyn Island show that about $8 \mathrm{~km}$ of lateral shortening of the ocean floor has taken place during accretion (Maruyama et al., 2010), comparable to that in the western Pacific where the process probably reached completion within $10 \mathrm{Ma}$. (Fig. 4)

\section{Distribution and time constraints of the Gwna Group mélange formation}

Mélange occurs in the northern, central and eastern areas of Anglesey as well as the west of Lleyn, the Skerries and Bardsey Island. Regarding the research done between 1985 and 1991, it is useful to compare the Precambrian- Cambrian rocks in Anglesey (including the adjacent Welsh mainland) with those of S.E. Ireland. Numerous authors contributed to our knowledge of these places, and ages, that are listed in "A revised correlation of Precambrian rocks in the British Isles, edited by W. Gibbons and A. L. Harris" (1994). Comparing S.E. Ireland with the Mona Complex rocks, it is only the Gwna Group in Anglesey and Lleyn that contains mélange, but the coeval Neoproterozoic Rosslare Terrane has none (Max, 1971). The Cambrian New Harbour and South Stack Groups in Anglesey do not contain mélanges, but the Cambrian Cahore and Cullenstown terranes do have mélanges, so accretion in S.E. Ireland commenced after the Gwna mélange emplacement had finished. Granite boulders (Coedana?) occur in the mélange matrix in Cemaes Bay. If the diamictite seen in Fig. 8 proves to be a tillite, then this would decrease the amount of time that it took for the mélange to be accreted, considerably.

\section{Anglesey mélange components}

The components of Anglesey's mélange consist of seabed sediments, generally mud-rich, though sometimes containing gritty/sandy horizons, enclosing olistoliths of sedimentary, metamorphic or volcanic material that were deposited on a basaltic ocean plate. Lesser quantities of ocean plate material, most commonly spilite, occur within the mélange as isolated blocks. Discrete inclusions, firstly on the surface and some later worked down into the muddy matrix can arrive from land masses, dropped by ocean currents, by ice, or they could be formed within an ocean e.g. from constructive margin deposits, at an island arc or from volcanic plumes (seamounts) that accumulate sedimentary deposits on their upper surfaces. Catastrophic slumping occurs regularly as land material, carried to the ocean by wind, rivers and ice, descends down the continental slope to the abyssal plains, where deep-sea muds (oozes) are common. This sea bed material, although consisting of the same materials as the true mélange are much more matrix-rich, though contain the same material as the tectonicallyemplaced mélange. This rock forms the extensive 


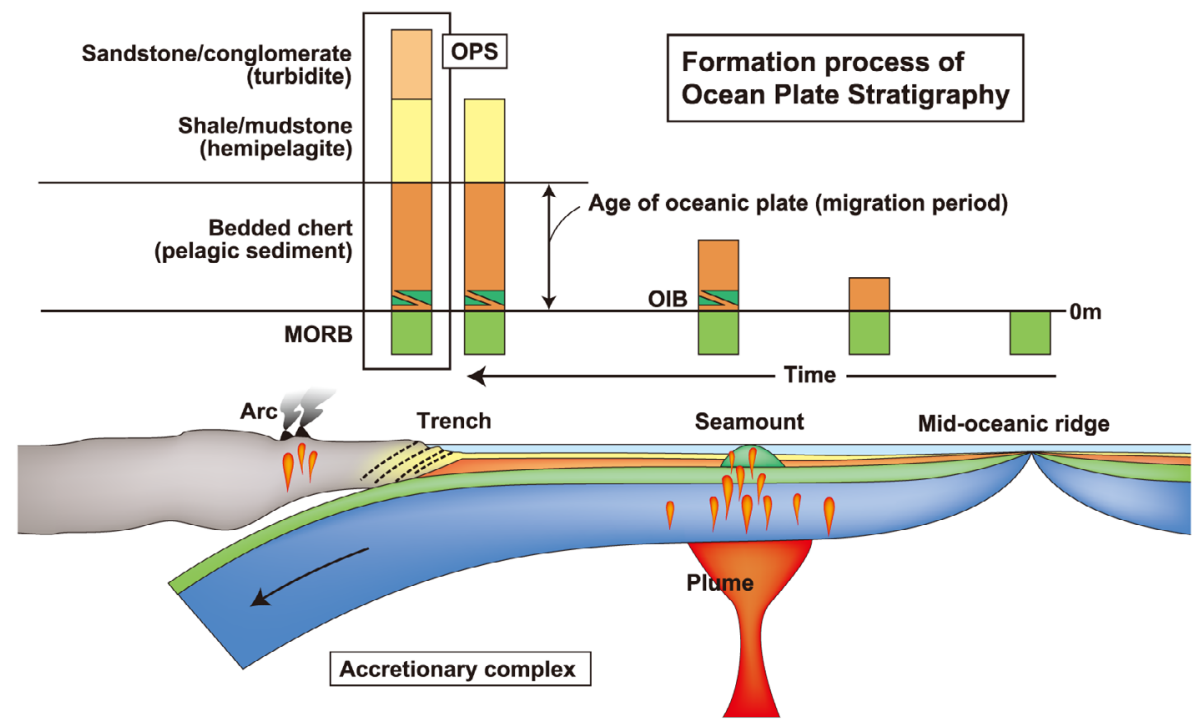

Fig. 3 A schematic illustration of an idealised travel history of Ocean Plate Stratigraphy from mid-ocean ridge to subduction zone (From Isozaki et al., 1990; Matsuda and Isozaki, 1991; Maruyama et al., 2010).

\section{Tremadoc-Caradoc, c. $488-448 \mathrm{Ma}$}

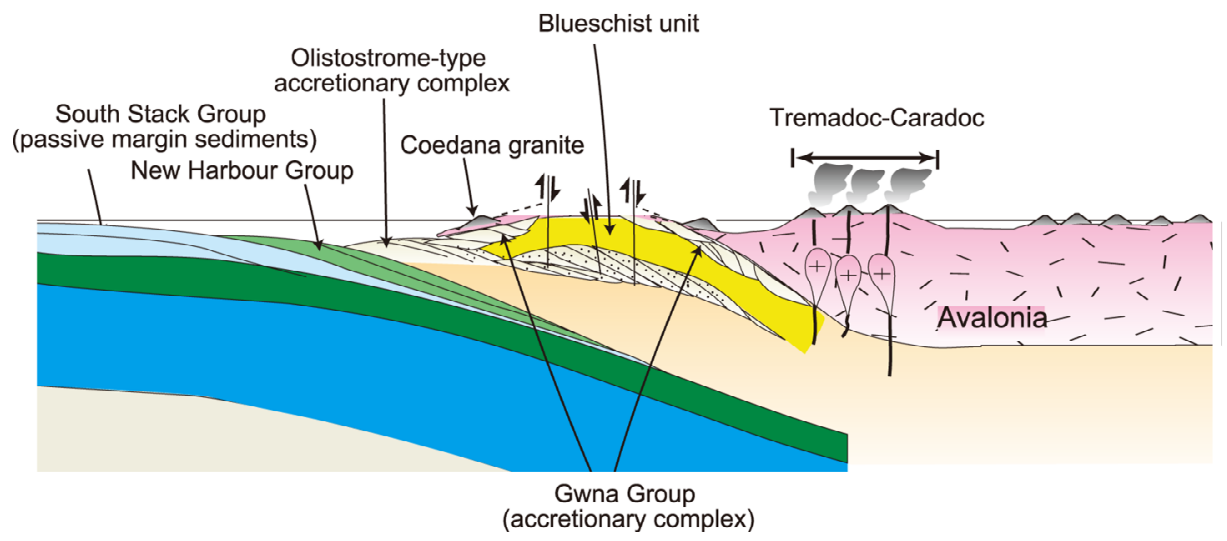

Fig. 4 A northwest to south-east cross section from Anglesey to Central England (from Maruyama et al., 2010). The South Stack and New Harbour Group underthrust the base of the accretionary edge during the final stages of subduction in the Cambrian. The underthrusting led to the doming of the accreted complex, as a result of which the Coedana Granite and gneisses became isolated from the western margin of Avalonia.

Green Schist deposits in Anglesey's Gwna Group of Precambrian rocks with occasional large, quartz-rich olistoliths as seen at Bwlch Gwyn, Henblas and Tan Lan in mid-Anglesey.

\section{The northern coast}

Mélange, tectonically-emplaced (Fig. 5), exists on Anglesey's northern coast, from Wylfa Nuclear Power Station to Llanbadrig Church (Fig. 6). It has remained in a sedimentary condition with two mega-clasts of stromatolitic limestone in a mélange matrix (East of Porth Padrig) and 'faulted in' Ordovician shales (Porth Padrig and east of Llanbadrig Church). In places, graphite, once 

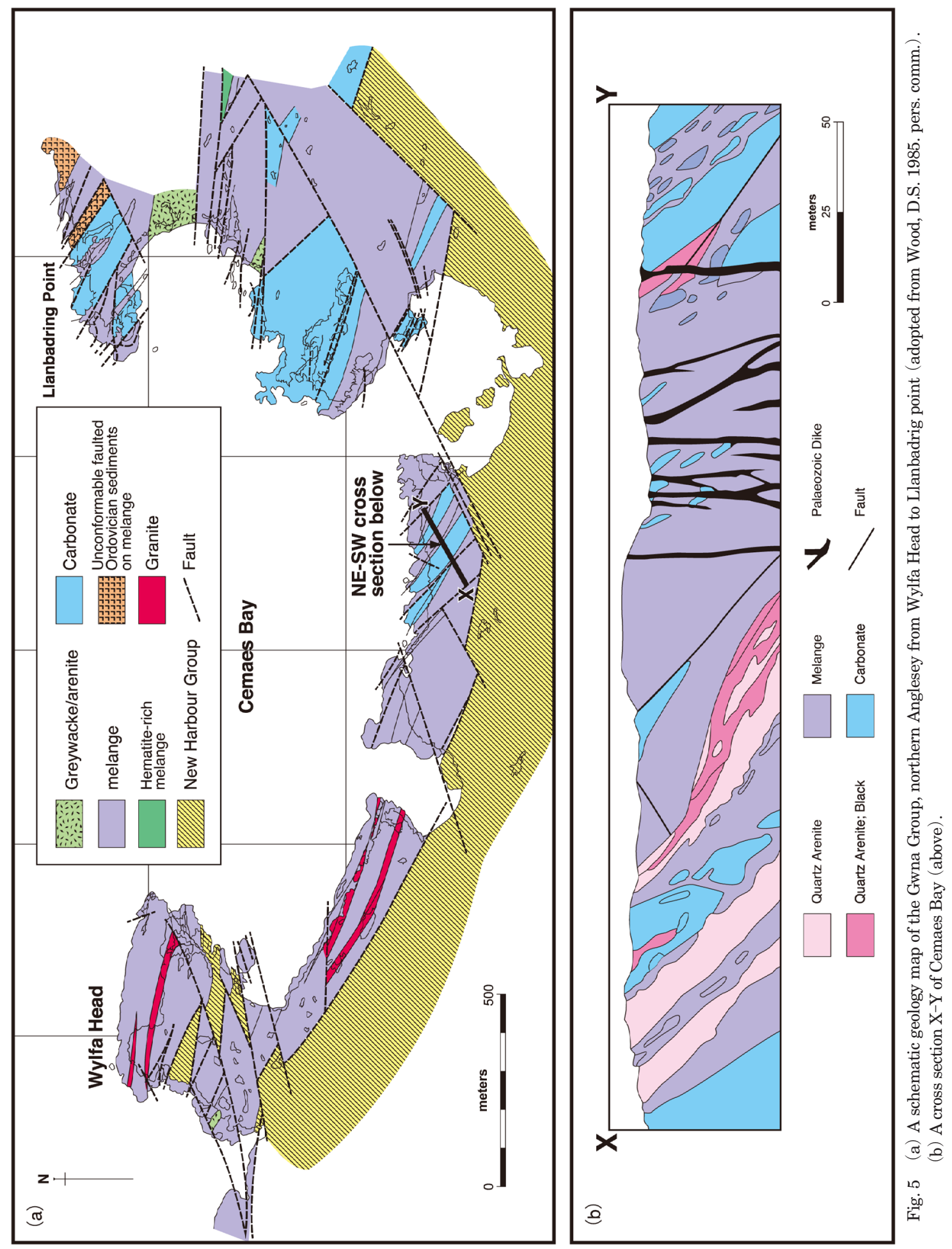
common, though now mostly weathered away, occurs on shear planes that possibly allowed the limestone in the mélange to be rafted, preventing it from crushing during Earth movements. Clasts mainly include quartz and limestone blocks (a hundred metres or more across) with subsidiary amounts of dolomite, ironstone (siderite) (Fig. 7), red chert (jasper), sandstone, phyllite and minor amounts of pillow lava. At contacts between the limestone and matrix, the limestone is dolomitised, therefore secondary. There are indications of both submarine sliding and fault emplacement of the mélange. One exposure of mélange on the northern edge of the massive limestone clast near Gadlys Quarry contains rounded exotic boulders and looks like a diamictite (possibly a tillite) (Fig. 8). If this is so, then it may relate to the dropstones of Llanddwyn that are thought to be the product of the Gaskiers Glacial or perhaps could be an earlier glaciation in the Precambrian, Sturtian $(700 \mathrm{Ma})$ or Marinoan (635 Ma).

On Llanbadrig peninsula, the cyanobacterial limestone (stromatolites) appears to be associated with the formation of the siderite and red chert clasts in both Llanddwyn and Llanbadrig areas. In the case of the siderite at Llanbadrig it also contains 'ghosts' pseudomorphs of rhombic crystals, suggesting a common original composition with later replacement of calcite by iron carbonate. Whilst filaments found in the red cherts of Llanddwyn are also found in the stromatolitic and pseudo oolitic limestones of Llanbadrig. Of particular interest in studying the origin of life-forms in the late Neoproterozoic are the above three rocks. The early Precambrian deep ocean anoxic conditions gradually gave way to an oxidising situation during the late Neoproterozoic as sufficient oxygen had been produced. Prokaryotic cyanobacteria were able to create mounds (stromatolites) and these blue-green algae were able to photosynthesize and therefore contributed to atmospheric oxygen. Similar fossils have now been found in 3.5 billion year old rocks. Although most of the deep oceans were anoxic, the first oxidation occurred in the late Neoproterozoic. Research in the deep oceans from Neoprotozoic to mid-Palaeozoic times was carried out by assess- ing the state of iron in Anglesey, Russia, Canada and Mongolia. Thus, widespread bacteria were contributing to atmospheric oxygen for 3.5 billion years. Anglesey's cyanobacteria were responsible for supplying oxygen to the atmosphere in the latter stages of the late Neoproterozoic, immediately before the 'Cambrian explosion'.

\section{The fossiliferous exposures in the limestone at Cemaes Bay}

Greenly in his 1919 memoir described what he called 'the linear limestones' in Gadlys Quarry and the rounded bodies in the rocks as oolites, Wood, M. and Nicholls, G. D. 1973 identified the linear limestone as stromatolites and the rounded bodies as vesicularites (another variety of cyanobacteria), Fig. 9. Further examination showed various branching and filament structures and pseudo-oolites. At a Limestone Symposium, Cambridge, 1972, participants considered them to be late Precambrian in age. They have since been dated as 800-860 Ma (Horák and Evans, 2011). In 1972 Wood and Nicholls revisited Gadlys Quarry, where at least four algal linear limestones with intervening fore reef material were recognised, as well as numerous branching, columnar and cabbage-like structures. Here also, was found the rarer 'conophyton', an angular volcano-like structure with pointed apex and 'parasitic' off-shoots on its sides. In Llanbadrig Quarry, the 'oolites' of Greenly were identified as cyanobacterial material 'vesicularites'. A branching stromatolite with 3 fronds and others broken off at their base has been found recently. An excellent stromatolitic bed with mounds and columns occurs intact around St Patricks Cave. Kanmera and Nishi (1983) first documented exotic limestone blocks of ancient mid-oceanic atolls in the Permian accretionary complex in SW Japan. The modes of occurrence of the abovementioned, shallow-water limestones in Anglesey are almost identical to those in Japan.

\section{The origin of the stromatolitic limestones of northern Anglesey}

The sufficiently warm seas around a convergent plate margin, and in particular around seamounts 

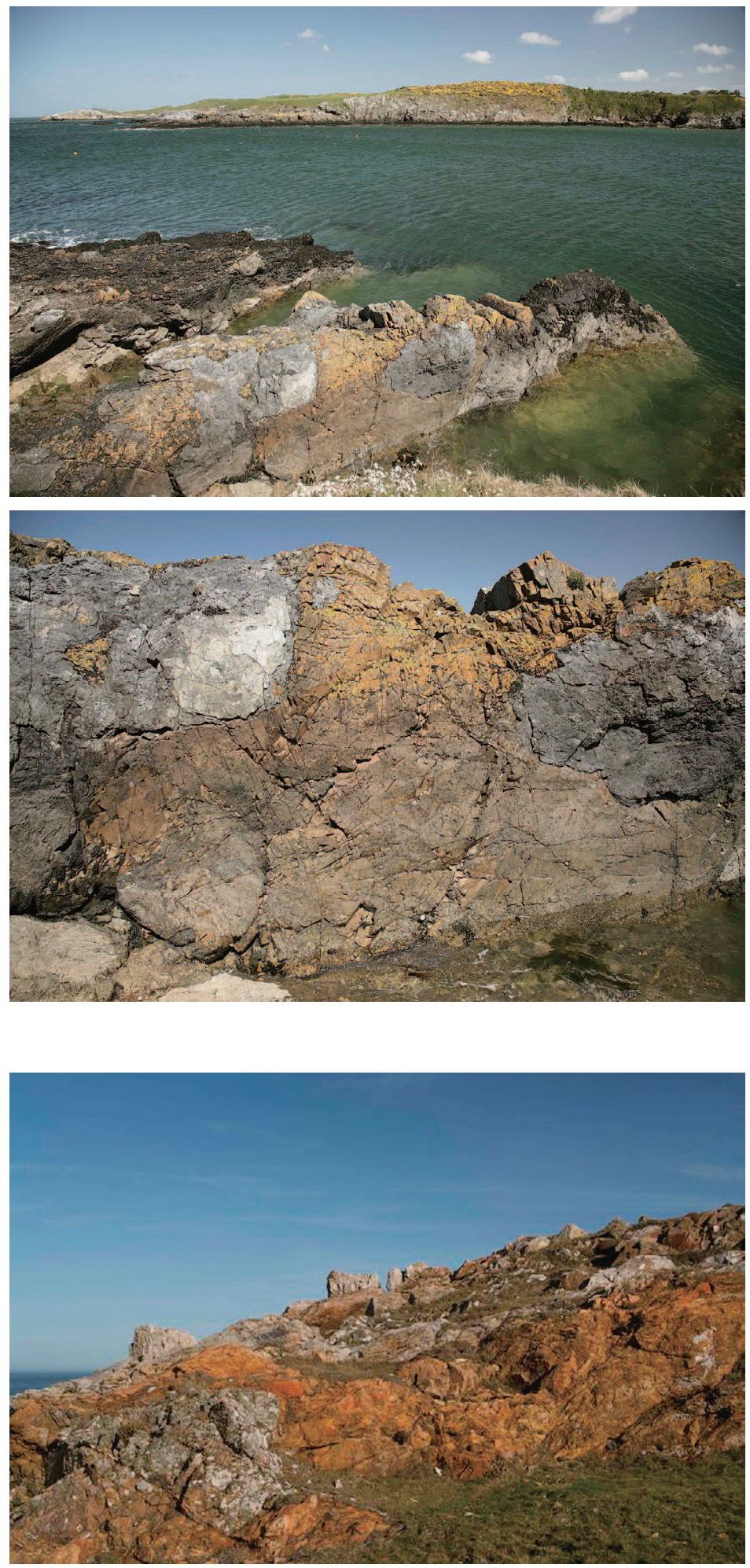

Fig. 6 A general view of Cemaes Bay. In the foreground, a weathered dyke within the mélange matrix with clasts of limestone and dolomite. Across the bay is the megaclast of limestone in the Gadlys Quarry area.

Fig. 7 The siderite clast in mélange matrix adjacent to limestone and sandstone clasts on Llanbadrig Point. 

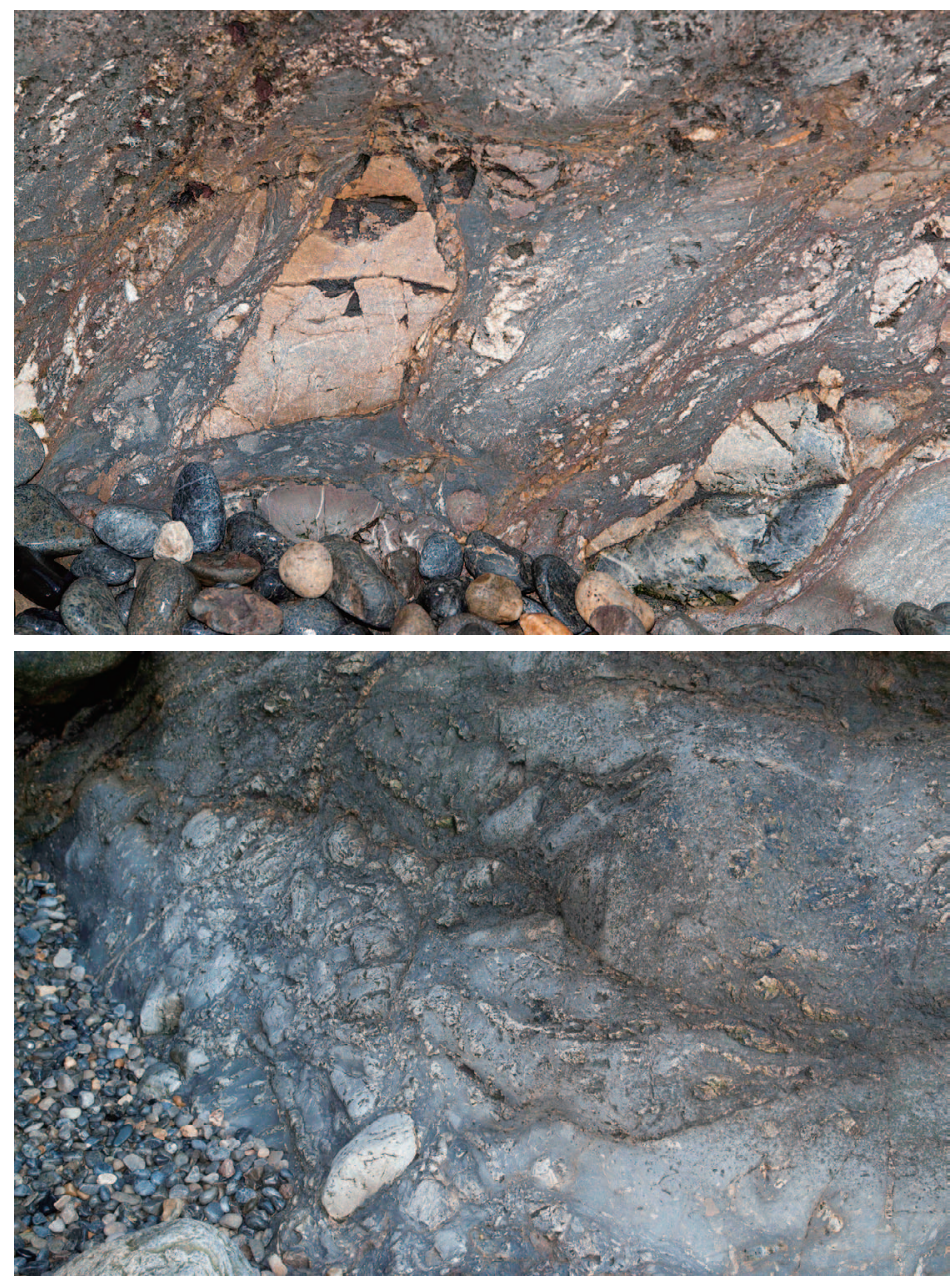

Fig. 8 The mélange beneath the northern edge of the mega limestone clast of Gadlys Quarry. The rounded pebbles and boulders, some of exotic rocks, indicate it could be a diamictite (tillite?).

(above plumes), provide a base for algal limestones to accumulate on the tops of these underwater volcanoes, whose angular apex has been eroded flat by wave action. The upper part receives sufficient sunlight to allow photosynthesis as occurs on atolls in tropical waters today. As stromatolites die, new filaments are produced that pierce the ca-rich sediment and a new layer is formed. The tops of seamounts, on their slow journey away from the constructive margin, gradually sink down relative to the sea-level, allowing more layers of limestone to accumulate. Limestone on the seamount would originate in shallow water. On reaching the trench, millions of years later, the limestone and fragments from the basaltic ocean crust beneath it were tectonically scraped off and accreted on to the underside of the hanging plate. Subsequent accreted material is emplaced below the pre-existing, older accreted rocks (mélange) and so additional accreted prisms are added during the life of a closing ocean. Thus the Gwna rocks, in this tectonic situation, occur at the top of the sequence, as opposed to a stratigraphic sequence in an ocean basin where the oldest rocks are at the bottom. However, some limestone clasts and other rocks in the mélange 


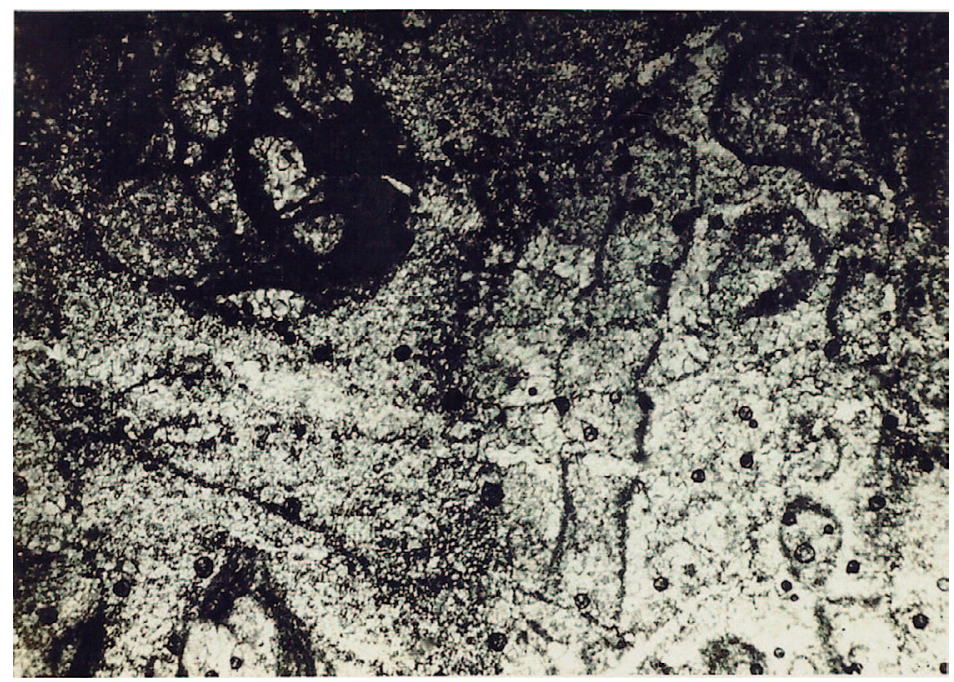

Fig. 9 The microscope section $(\times 20)$ that alerted the author $(1972)$ to view the Cemaes rocks as fossiliferous and not oolitic limestone as had been previously reported. Note the presence of pseudo-oolites (vesicularites), and one filament.

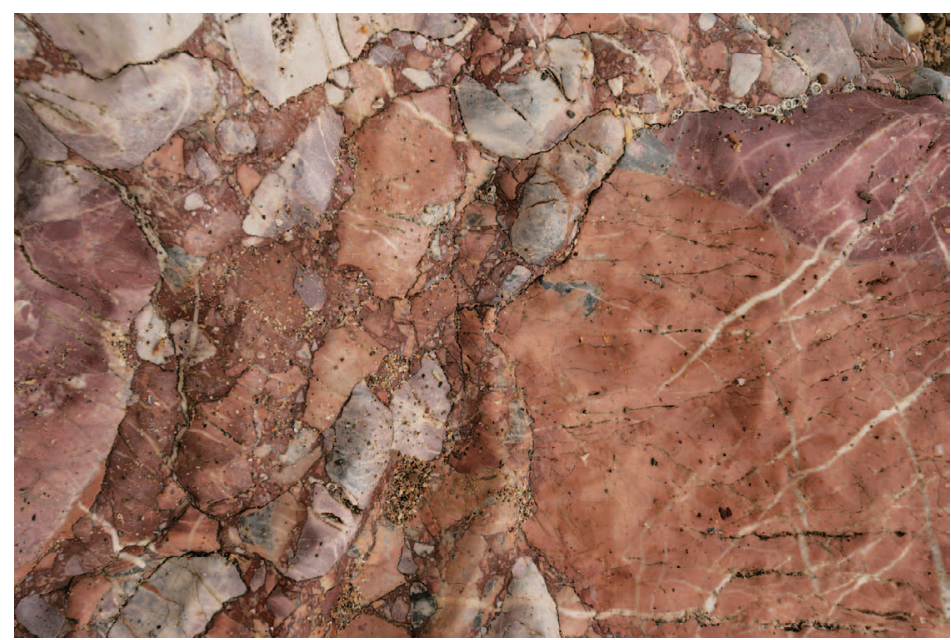

Fig. 10 Quartz boulders in quartz-cemented mélange in Pilots Cove, Llanddwyn Island, Anglesey.

have been found in a younger matrix. This can be explained by them being dislodged during a catastrophic event and dropped into younger mud slides or rocks. Catastrophic mud slides are common on the slope from the continental shelf to the abyssal plains and during earthquakes. Such force, if present near to a destructive plate margin, particularly at a time when an ocean closes, could easily dislodge fragmented sequences of already accreted mélange material. However, the age of the actual clasts will be that of its original formation. A similar clast of stromatolitic limestone, though much crushed, lies in juxtaposition with a metamorphosed, quartz-cemented, quartz boulder bed in Pilot's Cove, Llanddwyn Island and also probably originated in the same manner (Fig. 10). 


\section{Conclusion}

The mélange of Anglesey is pivotal in understanding the early formation of the British Isles from its journey beginning near the Antarctic circle to $54^{\circ} \mathrm{N}$ of the equator today and, the tectonic events that occurred on its journey. Anglesey and Lleyn mélange accretion occurred in Precambrian times (Gwna Group) that was completed before the Cambrian Period began. In S.E. Ireland there was no accretion of mélange in Precambrian times but it first appeared in Cambrian rocks. The Gwna mélange on the northern coast of Anglesey includes late Neoproterozoic fossils that were a vital element in producing the atmospheric oxygen we enjoy today and it does much to explain the mechanisms required to understand the processes involved in our life's evolutionary journey. This is the first time in Britain that fossils of this age have been recorded.

\section{Acknowledgements}

The author would like to acknowledge the help and inspiration in working on the problems of ancient Anglesey inspired by the late Dr G.D. Nicholls and Professor D.S. Wood. More recently, I am most grateful to Professor B.F. Windley of Leicester and Professor S. Maruyama and his team from Tokyo who have allowed me to work with them in a small way for the last 6 years and without whom I would not have had the joy of discovering the true nature of Anglesey's amazing past. Much of the contents of this paper were produced from their recent papers and I am very grateful to them for allowing me to use them and their diagrams in this paper. All the photos, except the microscope section, are the copyright of Stewart Campbell to whom I am most grateful.

\section{References}

Abbate, E.V., Bortolotti and Passerini, P. (1970): Olistostromes and olistoliths. Sedimentary Geology, 4, 521557.

Bailey, E.B. and McCallien, W.V. (1953): Serpentine lavas, Ankara Mélange and the Anatolian Thrust. Transactions of the Royal Society Edinburgh, 62, 403442.

Barber, A.J. and Max, M.D. (1979): A new look at the Mona Complex, (Anglesey, North Wales). Journal of the Geological Society, London, 136, 407-432.

Collins, A.S. and Buchan, C. (2004): Provenance and age constraints of the South Stack Group, Anglesey, UK. Journey of the Geological Society, London, 161, 743746.

Gansser, A. (1955): New aspects of the geology in Central Iran. Proceedings of the $4^{\text {th }}$ World Petrology Congress, Rome, Section I/A/5, 279-300.

Gibbons, W. and Harris, A.L. eds. (1994): A revised correlation of Precambrian rocks in the British Isles. Geological Society, London, Special Report, 22.

Geological Survey of England and Wales: Map of Anglesey (1840). Scale 1/63360. Geological Survey of Great Britain, London.

Greenly, E. (1919): The Geology of Anglesey. Memoir of the Geological Survey of Great Britain, 2 vol. HMSO, London. 980p.

Henslow, J.S. (1822): Geological description of Anglesea. Transactions of the Cambridge Philosophical Society, 1, 359-452.

Horák, J.M. and Evans, J.A. (2011): Early Neoproterozoic limestones from the Gwna Group, Anglesey. Geological Magazine, 148, 78-88.

Hsü, K.J. (1966): Principles of mélanges and their bearing on the Franciscan-Knoxville paradox. Geological Society of America Bulletin, 79, 1063-1074.

Isozaki, Y., Maruyama, S. and Furuoka, F. (1990): Accreted oceanic materials in Japan. Tectonophysics, 181, 179-205.

Kanmera, K. and Nishi, H. (1983): Accreted oceanic reef complex in Southwest Japan. in Accretion Tectonics in the Circum-Pacific Regions edited by Hashimoto, M. and Ueda, S., Terra Science, Tokyo, 195-206.

Kawai, T., Windley, B.F., Terabayashi, M., Yamamoto, H., Maruyama, S. and Isozaki, Y. (2006): Mineral isograds and metamorphic zones of the Anglesey blueschist belt, UK: implications for the metamorphic development of a Neoproterozoic subduction-accretion complex. Journal of Metamorphic Geology, 24, 591602.

Kawai, T., Windley, B.F., Terabayashi, M., Yamamoto, H., Maruyama, S., Omori, S., Shibuya, T., Sawaki, Y. and Isozaki, Y. (2007): Geotectonic framework of the blueschist unit on Anglesey-Lleyn, UK, and its role in the development of a Neoproterozoic accretionary orogen. Precambrian Research, 153, 11-28.

Leggett, J.G. (1987): The Southern Uplands as an accretionary prism: The importance of analogues in reconstructing palaeogeography. Journal of the Geological Society, London, 144, 737-751.

Maruyama, S., Kawai, T. and Windley, B.F. (2010): Ocean plate stratigraphy and its imbrication in an accretionary orogen: The Mona complex, Anglesey-Lleyn, Wales, UK. in The Evolving Continents: Understanding Processes of Continental Growth edited by Kusky, T.M., Zhai, M.G. and Xiao, W., Geological Society, London, Special Publications, 338, 55-75.

Matley, C.A. (1899): On the Geology of northern Anglesey. Quarterly Journal of the Geological Society, 
London, 55, 635-680.

Matley, C.A. (1890): On the geology of northern Anglesey. Part 2. Quarterly Journal of the Geological Society, London, 56, 233-256.

Matsuda, T. and Isozaki, Y. (1991): Well-documented travel history of Mesozoic pelagic cherts in Japan: from remote ocean to subduction zone. Tectonics, 10, 475-499.

Max, D. (1971): Two Precambrian Complexes in Ireland. Geological Survey of Ireland, Bulletin, 1, 99-105.

Muir, M.D., Bliss, G.M., Grant, P.R. and Fisher, M.J. (1979): Palaeontological evidence for the age of some supposedly Precambrian rocks in Anglesey. Journey of the Geological Society, London, 136, 61-64.

Raymond, L.A. ed. (1984): Mélanges: Their Nature, Origin and Significance. Geological Society of America,
Special Paper, 198, 170p.

Shackleton, R.M. (1953): The structural evolution of North Wales. Liverpool and Manchester Geological Journal, 1, 261-291.

Shackleton, R.M. (1954): The structure and succession of Anglesey and the Lleyn Peninsula. Advancements in Science, London, 11 (41), 106-108.

Wood, D.S. (1974): Ophiolites, mélanges, blueschists and ignimbrites, early Caledonian subduction in Wales? in Modern and Ancient Geosynclinal Sedimentation edited by Dott, H.R.Jr. and Shaver, R.H., Society of Economic Paleontologists and Mineralogists, Special Publication, 19, 334-344.

Wood, M. and Nicholls, G.D. (1973): Precambrian stromatolitic limestones from Northern Anglesey. Nature, 241, 65. 


\section{用語としての「メランジュ」の歴史的変遷と 英国ウエールズ州アングルシー・スリン地域の 先カンブリア界地質との関連$$
\text { マーガレット・ウッド* }
$$

基質に混在した岩塊を含む「メランジュ」を， グリーンリー（1919）が世界ではじめてアング ルシーで記載した。それ以来, この地はメラン ジュの模式地となった。アングルシー島の大部分 およびスリン半島西部は先カンブリア紀後期から カンブリア紀のモナ複合岩体から構成され，欧州 に産する低変成度付加型造山帯の最良の例を提示 している。これらの岩石は, 現在の太平洋西部の
プレート沈み込み帯上の前弧域に比較される場で 付加した構造的な地質体であり，ゆえに海洋プ レート層序をもつことを特徵とする。本稿は，モ ナ複合岩体およびそのメランジュの形成史に関す る解釈が，過去 200 年間にどのように変化した のかについて記述する。さらに同メランジュがも つ多様性，また古期生命との関連についても議論 する。

キーワード : 先カンブリア時代, テクトニクス, 付加, ストロマトライト, アングルシー 